\title{
The ability to solve physics problems in symbolic and numeric representations
}

\author{
Umrotul, Aurelia Astria L. Jewaru, Sentot Kusairi, and Nugroho Adi Pramono \\ Universitas Negeri Malang, Malang, Indonesia. \\ e-mail: umrotul.1903218@students.um.ac.id; aurelia271097@gmail.com; \\ sentot.kusairi.fmipa@um.ac.id; nugroho.adi.pramono@um.ac.id
}

Received 13 July 2021; accepted 10 September2021

\begin{abstract}
The aim of this study is to analyze the ability of students to solve the problems of linear motion kinematics expressed in symbolic and numeric representation. Research was survey with cross-sectional design. Research subjects included 26 first year undergraduate students in physics at one of the State Universities in Malang which was consisted of 10 men and 16 women. The research instrument was openended test of linear motion kinematics problems expressed in symbolic and numeric representations with a reability 0.807 . The research data were analyzed using descriptive statistics. The results showed that students had difficulty solving linier motion kinematics problems in both representations but problems in symbolic representations were more difficult for students to solve than numeric representations. The study suggested further research to explore the causes of student difficulties more authentically, e.g. by interviewing or thinking aloud.
\end{abstract}

Keywords: Symbolic representation; numeric representation; problem solving; linear motion kinematics.

DOI: https://doi.org/10.31349/RevMexFisE.19.010209

\section{Introduction}

The use of multiple representations is one of the important skill that is needed by students to succed in learning physics. Multiple representations in physics can be in the form of words, pictures, diagrams, graphs, computer simulations, mathematical equations, etc [1-5]. Multiple representations can be effective improve understanding of physics concepts as well as problem solving skills $[5,6]$. The use of multiple representations can also be used to describe information more clearly so that it can affect students' abilities and strategies in solving problems $[7,8]$.

Kinematics is one of the basic physics materials that is closely related to representation in learning. According to Ref. [9], to improve understanding of kinematic concepts, students must understand several representations. Some of the representations that students must understand in basic physics include graphics, verbal, pictures, and mathematical equations [10]. Therefore, kinematics is an important material that is also challenging for students [11].

In fact, students have difficulties in solving kinematics problems related to multiple representations. Some studies reveal that students have difficulties in understanding kinematics graphs [1,12-17]. Research also found many students in universities have difficulties to solve kinematics problems in symbolic representation rather than numeric representation [18]. Result of pretest in Ref. [9] research where students were asked to determine the velocity of two objects based on a motion diagram showed that only $2.9 \%$ of students answered correctly.

Based on the explanation above, the difficulty of students in kinematic graphs is an issue that most researchers pay attention, but students' ability to solve kinematics problems in other representations such as symbolic and numeric representations are still not of concern in research. In previous research [18] Torigoe used multiple choice test of kinematics problems in symbolic and numeric representation which aims to measure differences in students' performance when solving kinematics problems in different representations. The results showed that there were some students' difficulties when solving kinematics problems in symbolic representations. Students' difficulties when solving the problems in symbolic representation are caused by confusing the meaning of variables in symbolic representation [18], inability to interpret physics equations [19], and confusing of known and unknown symbols in equestions [20]. This is also indicated by the result of the mean score of the questions that used symbols were lower than the questions that did not [18].

As has been explained, research on the differences in students' ability to solve kinematics problems in symbolic and numeric representations has been carried out abroad but in Indonesia it has never been done. Based on research location, education in Indonesia is different from foreign countries. Teachers and lecturers in this country often use numeric representations in explaining physics material and applying it in exams. So that students are used to solving physics problems in numeric representations, but rarely even almost never solve problems in symbolic representations. In reality, the use of symbols in learning are closely related to equations, have conceptual and physical meaning in understanding physics concepts [21]. The purpose of learning with symbols contained in physics equations is that students are able to interpret the relationship between symbols and physical meanings. However, students are required to not only understand physics using mathematics but also understand mathematics in the concept of physics [22].

Based on this phenomenon, this study wants to analyze the students' ability to solve kinematics problems in symbolic and numeric representations more explicitly in Indonesia. This study will also reveal students' understanding of 
distance and constant acceleration concept in symbolic and numeric representations. Algebra is also one of the skills that needed by students when solving kinematics problems in symbolic representations. According to Ref. [18], for some student, the lack of algebraic facilities act as barrier to succes in physics. The students' difficulties in understanding symbols will interfere their performance when solving problems in symbolic representations. Based on the explanation in front, students have not mastered the concept of linier motion kinematics properly which also will have an impact on their ability to solve problems in multiple representations.

The purpose of this study was to analyze the ability of students to solve kinematics problems in linier motion in symbolic and numeric representations. Two research questions raised are as follows. 1. How is the ability of students to solve the problem of linear motion kinematics in symbolic and numeric representations? 2. Which problems in representation are more difficult for students to solve?

\section{Method}

\subsection{Research design}

This research used survey model approach with crosssectional design. The data of this study was quantitative. The initial step in data collection was giving open-ended test to students. Respondents will work on the problems individually in thirty minutes in class. After that, the student's answer sheets that have been collected are scored conventionally with rubric that made by researchers. The assessment rubric can be seen in Appendix B.

\subsection{Participants}

The subjects of this research are first year undergraduate students majoring in physics at one of the state universities in Malang who were currently pursuing fundamenal physics in $2019 / 2020$ academic year. The total population of first year physics undergraduate students this research in were $96 \mathrm{stu}-$ dents. There were 3 classes in the physics department in the first year undergraduate students in 2019, 1 class was chosen by random sampling as the research sample. The number of respondents were 26 undergraduate students consisting of 10 men and 16 women. The age of the respondents ranged from 17 to 20 years and respondents were selected based on convenience sampling. Respondents who participated in the study were small sample because researchers cannot collect more data caused COVID-19 pandemic. The study was conducted in four months starting from August to November 2019.

\subsection{Research instrument}

The instrument used in this research was open-ended test with a reability 0.807 The questions were adopted and
1. A car which is initially silence moves to the right so that it reaches speed $f_{l}$ in $d_{l}$ seconds. As the picture below.

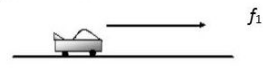

What is the distance traveled by the car when the speed is $f_{1} / 2$ ? (assume that the acceleration is constant)

Answer:

FIGURE 1. The example of kinematics question number 1 in symbolic representation.

\begin{tabular}{|c|c|c|}
\hline Item & Concept and & \\
\hline Number & $\begin{array}{c}\text { Type of } \\
\text { Representation }\end{array}$ & Indicators \\
\hline 1 & $\begin{array}{c}\text { Distance } \\
\text { (Symbolic) }\end{array}$ & $\begin{array}{l}\text { Determine the distance } \\
\text { traveled by a car based on } \\
\text { known quantities in symbol. }\end{array}$ \\
\hline 2 & $\begin{array}{l}\text { Constant } \\
\text { acceleration } \\
\text { (Symbolic) }\end{array}$ & $\begin{array}{c}\text { Determine minimum } \\
\text { acceleration based on known } \\
\text { quantities in symbol. }\end{array}$ \\
\hline 3 & $\begin{array}{l}\text { Distance } \\
\text { (Numeric) }\end{array}$ & $\begin{array}{c}\text { Determine the distance traveled } \\
\text { by a car based on known } \\
\text { quantities in numeric. }\end{array}$ \\
\hline 4 & $\begin{array}{l}\text { Constant } \\
\text { acceleration } \\
\text { (Numeric) }\end{array}$ & $\begin{array}{l}\text { Determine minimum } \\
\text { acceleration based on known } \\
\text { quantities in numeric. }\end{array}$ \\
\hline
\end{tabular}

adapted from multiple choice test of kinematics concepts in symbolic and numeric represention [18]. The researchers choose open-ended test because its have been designed to reduce students' cheating in exams. The questions of instruments are two pairs of linier motion kinematics questions consisting of four questions. Indicators for each question can be seen in Table I.

Uncommon variables in kinematics are used in questions on symbolic representation such as the variable $f$ for speed, $d$ for travel time, and $b$ for distance. The example of question number 1 can be seen on Fig. 1 .

\subsection{Data analysis}

Data was analyzed with descriptive statistics. Descriptive analysis explains mean, standard deviation, highest score, and lowest score. The problems which is more difficult to solve by students can be seen from the correct percentage of each problems in representations.

\section{Result and discussion}

The students' ability to solve linear motion kinematics problems can be seen from the scores obtained by students which 


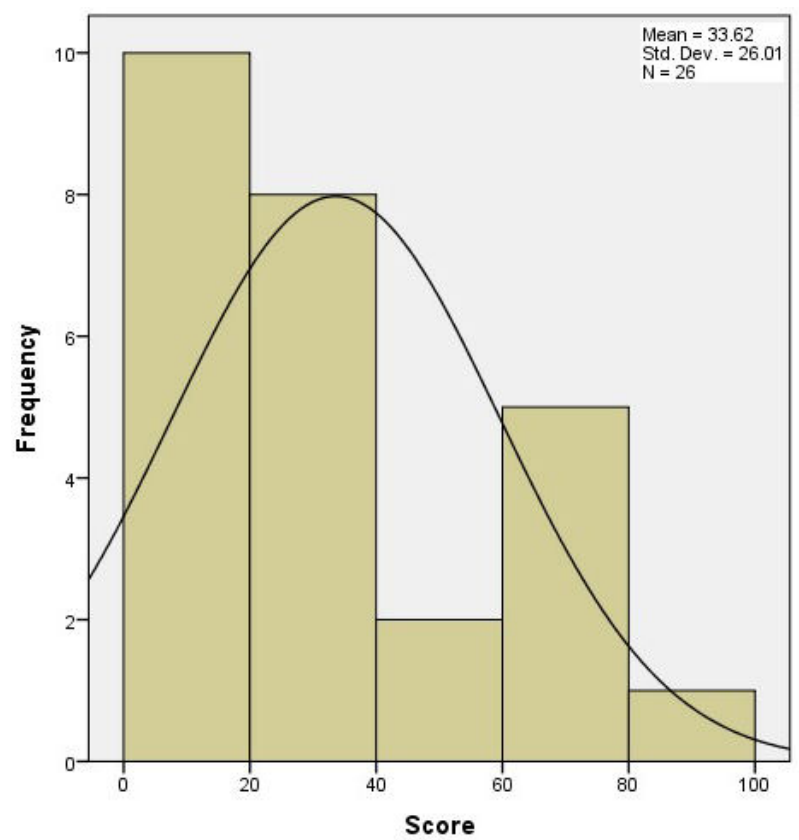

FIGURE 2. Histogram of scores obtained by students.

are presented in the histogram on Fig. 2. Based on Fig. 2, the scores obtained by students with the highest frequency are in the range of 0 to 20 .

The student's ability to solve linier motion kinematics problems can be seen from mean score of students in descriptive statistics. Descriptive statistic of student's score presented in Table II.

Linier motion kinematics problems representation that are more difficult to solve by students than others can be seen by the lower mean among other problems. Descriptive statistics of students' scores on each problem presented on Table III. Based on Table III, the result of descriptive statistics test showed that item number 1 and 2 which are questions in symbolic representation have mean scores lower than number 3 and 4 which are numeric representation. This findings are the same as the result of research by [18] which stated that the mean score of the questions that used symbols were

TABLE II. Descriptive statistics of students' scores.

\begin{tabular}{ccccc}
\hline $\mathrm{N}$ & $\begin{array}{c}\text { Lowest } \\
\text { score }\end{array}$ & $\begin{array}{c}\text { Highest } \\
\text { score }\end{array}$ & mean & $\begin{array}{c}\text { Standart } \\
\text { deviasi }\end{array}$ \\
\hline 26 & 2 & 100 & 33.59 & 26.00 \\
\hline
\end{tabular}

TABLE III. Descriptive statistics of students' scores on each problem.

\begin{tabular}{ccccc}
\hline item & $\begin{array}{c}\text { Lowest } \\
\text { score }\end{array}$ & $\begin{array}{c}\text { Highest } \\
\text { score }\end{array}$ & mean & $\begin{array}{c}\text { Standart } \\
\text { deviasi }\end{array}$ \\
\hline 1 & 0 & 25 & 6.750 & 9.1228 \\
2 & 0 & 25 & 6.077 & 5.5636 \\
3 & 0 & 25 & 11.558 & 9.7492 \\
4 & 0 & 25 & 9.212 & 7.6134 \\
\hline
\end{tabular}

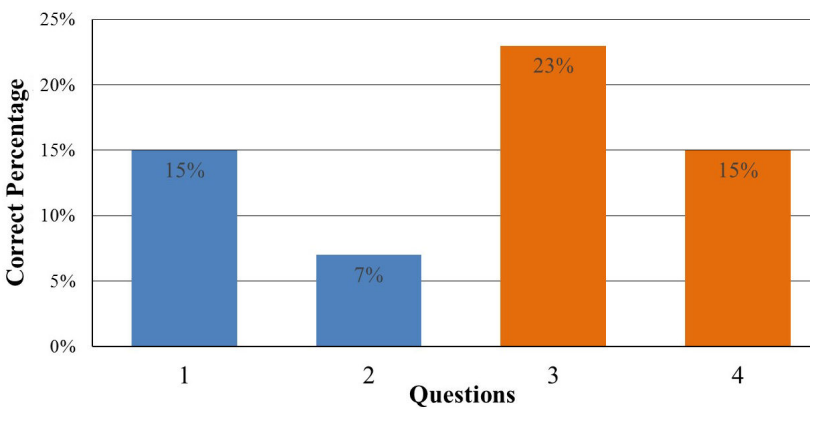

FIGURE 3. Correct percentages of linier motion kinematics problems.

lower than the questions that did not. This result of study showed that kinematics questions in symbolic representations are more difficult for students to solve than numeric representations.

Problems which are more difficult for students to solve also can be seen in the correct percentage of questions on Fig. 3. Based on the Fig. 3, the lower correct percentage of questions is number 1 and 2 which are questions of distance and acceleration concept in symbolic representation.

The result of this study indicated that the ability of students to solve distance and constant acceleration concept between symbolic and numeric representation was different. It showed that the context of question in different representations can affect students' ability to solve the problems. There are two questions that are the more difficut to solve for students. Two questions are number 1 and 2 which are in symbolic represention.

Question number 1 is about distance concept that students are asked to determine the distance traveled by the car when the speed is $f_{1} / 2$. Students who understand the concept of distance will answer correctly althought faced with questions in symbolic representations. So students' abilities to solve problems will not be affected by questions in different forms of representation. The correct answer for number 1 is $s=f_{1} d_{1} / 8$. There were 4 students who answered correctly and 22 students who answered incorrectly in with various answers. Students answered incorrectly in number 1 caused by misinterpreting the initial speed of car, misinterpreting the initial speed and time when the speed is $f_{1} / 2$, and using incorrect equations. The use of the incorrect equations was the most students' fail when solving number 1 . These results indicate that most of students do not understand the distance concept but only memorize the equations that are used to solve problems. The result of the study is consistent with the findings of $[1,18]$ which students have difficulty in representing symbolic questions because conceptual understanding is still limited and there was work that inderterminate such as many conflicting equations. The example of student's incorrect answer for Question number 1 caused by using incorrect equations can see in Fig. 4.

Question number 2 is about constant acceleration concept that students are asked to determine the minimum acceleration of Budi in order to overtake Ani in the distance $b$. The 


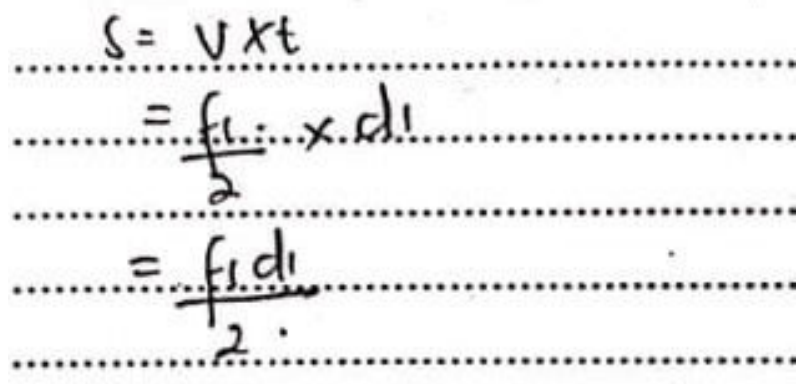

FIGURE 4. Example of incorrect equations to solve question number 1 .

correct answer for number 2 is a $\vec{a}_{\text {min }}=2\left(f^{2} / b\right)$. There were 2 students who answered correctly and 24 students who answered incorrectly in various answers. Some obstacles when solving number 2 students have difficult for understanding the context of questions, subtituting symbol, and using equations. The use of the incorrect equations also was the most students' fail when solving number 2 . These results indicate that students do not understand physical context but only memorize the equations that are used to solve problems. The difficulty in understanding the context of number 2 is when students misunderstand Budi's acceleration in chasing Ani to get to the gate. When Budi wakes up and chases Ani, Budi's speed is zero. This is one of the uses equations in linier motion kinematics for constant acceleration concept. Therefore, the correct equation for determining the minimum acceleration Budi chases Ani is $s=v_{\text {initial }} t+(1 / 2) \vec{a} t^{2}$. But many students have written incorrect equations to solve number 2 . The result of the study are consistent with the findings of some researchers. When students were solving the physics problem in symbolic representation, they have difficulty in understanding physical context [23] and interpreting physical equations [24].

This result also showed that the most students who failed to solve the problems answered by incorrect equations. It showed that the students' failure to solve the problems in representations was not about the lack of manipulation in mathematics but the conceptual understanding of students. This finding also is same as the result of previous research The previous research stated that students who had the lack of knowledge of mathematics is not the main reason for stu-

TABLE IV. Student's answers in symbolic representations.

\begin{tabular}{|c|c|c|}
\hline Concept & Answer & Number of Students \\
\hline \multirow[t]{10}{*}{ Distance } & Correct & 4 \\
\hline & Using equations & 2 \\
\hline & $\begin{array}{l}f_{1}=a d_{1} \\
\left(\frac{f_{1}}{2}\right)^{2}=f_{1}^{2}+2 \frac{f_{1}}{d_{1}} s \quad \text { atau } \quad s=f_{1} \frac{d_{1}}{2}+\frac{1}{2} \frac{f_{1}}{d_{1}}\left(\frac{d_{1}}{2}\right) \\
\text { but misinterprets the initial speed when the speed is } \frac{f_{1}}{2} \text {. }\end{array}$ & \\
\hline & Result $\quad S=-\frac{3 f_{1} d_{1}}{8} \quad$ and $\quad S=\frac{3 f_{1} d_{1}}{4}$ & \\
\hline & Using equations & 1 \\
\hline & $\begin{array}{l}\frac{f_{1}}{2}=f_{1}+a d_{1}, \quad \text { dan } \quad s=f_{1} d_{1}+\frac{1}{2} a d_{1}^{2} \\
\text { misinterpret the initial speed and the time when speed is } \frac{f_{1}}{2} \text {. }\end{array}$ & \\
\hline & The result is $s=\frac{f_{1} d_{1}}{4}$ & \\
\hline & Using equations & 6 \\
\hline & $S=f_{1} d_{1}$, the result is $S=\frac{f_{1}}{2} x \frac{d_{1}}{2}$. & \\
\hline & Using incorrect equations & 13 \\
\hline \multirow{8}{*}{$\begin{array}{c}\text { Constant } \\
\text { acceleration }\end{array}$} & Correct & 2 \\
\hline & Using equations & 2 \\
\hline & $t=\frac{s}{f}$ dan $s=\frac{1}{2} a\left(\frac{s}{f}\right)^{2}$ & \\
\hline & $\begin{array}{l}\text { but it is wrong to substitute symbols in the equation the result is } \\
a=\frac{2 f^{2}}{s} \text { or } a=\frac{2 v^{2}}{b} \text {. }\end{array}$ & \\
\hline & Obtain $t=\frac{b}{f}$ & 9 \\
\hline & But it is wrong to use the equation to determine the minimum acceleration & \\
\hline & Using a wrong equation & 11 \\
\hline & Answering wrong with reasoning & 2 \\
\hline
\end{tabular}




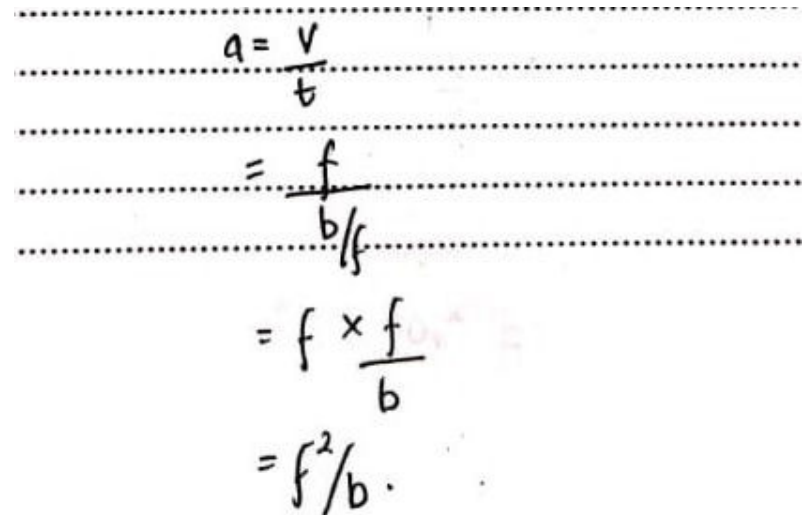

FIGURE 5. Example of incorrect equations to solve question number 2 .

dents' difficulties in solving physics but the understanding of concepts was the biggest problem for students in solving physics problems [14]. In other side Ref. [19] stated that students confusion to solve kinematics problems in symbolic representations is created because the same symbols will appear with more than one in the second equation during the solving process. The example of student's incorrect answer for number 2 can be seen in Fig. 5.

Students' answers and number of students when solving distance and constant acceleration concept in symbolic representation are presented in the Table IV.

\section{Suggession and recommendations}

The results of the study provide several suggession and recommendations so that students can solve problems better in a multiple representation and understand physics concepts. Teachers can do learning physics using multiple representations, provide practice questions or tests, and challenge learning about diverse representations in solving physical problems [25]. The ability to interpret many representations needs to be assisted by the teacher by teaching the correct understanding of concepts, therefore the teacher must prepare the material well [26]. Some weaknesses in research include relatively small research data using only classes taught by the same lecturers and students.

\section{Conclusion}

The results showed that students have difficulty solving kinematics problems both representations but problem solving in symbolic representations is more difficult than numeric representations. It is recommended in learning physics not only provides numeric based tests but also uses multiple representations because it can help students solve problems and understand the concepts of physics. The impact of research for students is that they can know that the same linier motion kinematics question but different representations will affect their performance in solving problems. Researchers can also find out that there are some student difficulties in solving kinemantics problems of straight motion in symbolic and numeric representations.

\section{Appendix}

\section{A. Instrument test}

1. A car which is initially silence moves to the right so that it reaches speed $f_{1}$ in $d_{1}$ seconds. As the picture below.

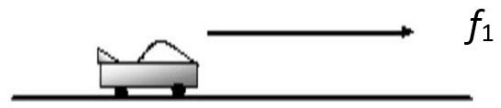

What is the distance traveled by the car when the speed is $f_{1} / 2$ ? (assume that the acceleration is constant)

Answer :

2. Budi and Ani are racing towards the school gate. Budi ran quickly leading the way in front of Ani. When Budi is almost at the school gate, he decides to take a break. A few moments later, Ani catches up with constant speed $f$ past Budi, who is sitting resting at a distance of $b$ from the school gate. Just as Ani passes Budi, Budi runs up and runs at a constant speed to get to the school gate first. What is the minimum acceleration for Budi to reach the school gate before Ani?

Answer :

3. A car which is initially silence moves to the right so that it reaches speed $60 \mathrm{~m} / \mathrm{s}$ in 8 seconds. As the picture below.

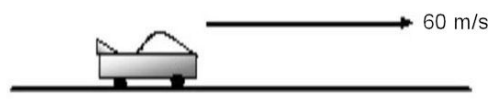

What is the distance traveled by the car when the speed is $30 \mathrm{~m} / \mathrm{s}$ ? (assume that the acceleration is constant).

Answer :

4. Budi and Ani are racing towards the school gate. Budi ran quickly leading the way in front of Ani. When Budi is almost at the school gate, he decides to take a break. A few moments later, Ani catches up with constant speed $2 \mathrm{~m} / \mathrm{s}$ past Budi, who is sitting resting at a distance of $500 \mathrm{~m}$ from the school gate. Just as Ani passes Budi, Budi runs up and runs at a constant speed to get to the school gate first. What is the minimum acceleration for Budi to reach the school gate before Ani?

Answer: 


\section{B. Assessment rubric}

\begin{tabular}{|c|c|c|c|}
\hline \multirow{2}{*}{$\begin{array}{c}\text { Item } \\
\text { Number }\end{array}$} & \multicolumn{2}{|c|}{ Representation } & \multirow[t]{2}{*}{ Assessment Rubric } \\
\hline & Symbolic & Numeric & \\
\hline $\begin{array}{l}1 \& 3 \\
\text { (distance } \\
\text { concept) }\end{array}$ & $\begin{array}{l}\text { Step 1: Write the equation } \\
\qquad v_{(t)}=v_{o}+\vec{a} t \\
\quad v_{(t)}{ }^{2}=v_{o}^{2}+2 \vec{a} \cdot \vec{s} \\
\text { Step } 2 \text { : Substitution values into } \\
\text { equations } \\
\quad v_{(t)}=v_{0}+\vec{a} t \\
\quad v_{(d 1)}=f_{1} \\
f_{1}=0+\vec{a} d_{1} \\
\text { and } \\
v_{(t)}{ }^{2}=v_{o}^{2}+2 \vec{a} \cdot \vec{s} \\
\quad\left(\frac{f 1}{2}\right)^{2}=0^{2}+2 \vec{a} \cdot \vec{s} \\
\text { Step } 3: \text { Complete calculation } \\
\vec{a}=\frac{f_{1}}{d 1} \\
\text { and } \frac{f_{1}^{2}}{4}=2 \frac{f_{1}}{d_{1}} s \\
\quad s=\frac{f 1 d 1}{8}\end{array}$ & $\begin{array}{l}\text { Step 1: Write the equation } \\
\qquad v_{(t)}=v_{o}+\vec{a} t \\
\quad v_{(t)}{ }^{2}=v_{o}{ }^{2}+2 \vec{a} \cdot \vec{s} \\
\text { Step } 2 \text { : Substitution values into } \\
\text { equations } \\
\quad v_{(t)}=v_{0}+\vec{a} t \\
\quad v_{(8)}=60 \mathrm{~m} / \mathrm{s} \\
\quad 60 \mathrm{~m} / \mathrm{s}=0+\vec{a} 8 \mathrm{~s} \\
\text { and } \\
\quad v_{(t)}{ }^{2}=v_{o}{ }^{2}+2 \vec{a} \cdot \vec{s} \\
\quad(30 \mathrm{~m} / \mathrm{s})^{2}=0^{2}+2 \vec{a} . \vec{s} \\
\text { Step } 3: \text { Complete calculation } \\
\vec{a}=\frac{60 \mathrm{~m} / \mathrm{s}}{8 \mathrm{~s}}=7,5 \mathrm{~m} / \mathrm{s}^{2} \\
\text { and } \quad 900=2(7,5) S \\
S=60 \mathrm{~m}\end{array}$ & $\begin{array}{l}\text { Score } 25=\text { complete } \\
\text { steps and correct } \\
\text { answers } \\
\text { Score } 20=\text { steps } 2 \text { and } \\
3 \text { and the } \\
\text { answer is } \\
\text { correct } \\
\text { Score } 15=\text { steps } 1 \text { and } \\
2 \text { correctly } \\
\text { Score } 10=\text { steps } 2 \text { or } 3 \\
\text { correctly } \\
\text { Score } 5=\text { step } 1 \\
\text { correctly } \\
\text { Score } 0=\text { wrong } \\
\text { answer with } \\
\text { wrong steps } \\
\text { or not answer }\end{array}$ \\
\hline $\begin{array}{l}2 \& 4 \\
\text { (constant } \\
\text { accelerat } \\
\text { ion) }\end{array}$ & $\begin{array}{l}\text { Step 1: Write the equation } \\
\qquad \begin{array}{c}v=s t \\
\text { And }\end{array} \\
\qquad s=v_{0} t+\frac{1}{2} a t^{2} \\
\text { Step 2 : Substitution values into } \\
\text { equations } \\
\qquad t=\frac{b}{f} \\
\text { and } \\
\text { Step } 3 \text { : Complete calculation } \\
\vec{a}_{\text {min }}=2 \frac{f^{2}}{b}\end{array}$ & 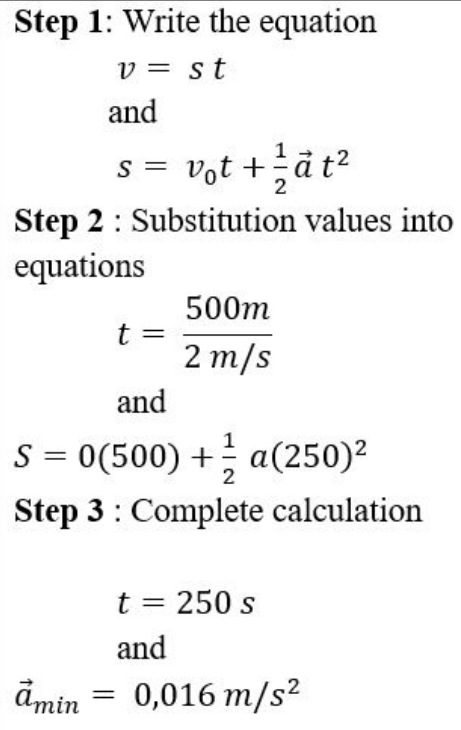 & \\
\hline
\end{tabular}

\section{Acknowledgments}

With the completion of this article, the author would like to thank Drs.Purbo Suwasono, M.Si as the lecturer of kinematic courses for kind support. 
1. L. Bollen, P. Van Kampen, C. Baily, M. Kelly, and M. De Cock, Student difficulties regarding symbolic and graphical representations of vector fields, Phys. Rev. Phys. Educ. Res. 13 (2017) doi: $10.1103 /$ PhysRevPhysEducRes.13.020109

2. M. De Cock, Representation use and strategy choice in physics problem solving, Phys. Rev. Spec. Top.-Phys. Educ. Res. 8 (2012) 1. doi: $10.1103 /$ PhysRevSTPER.8.020117

3. S. Furwati, Sutopo, and Zubaidah, PENINGKATAN PEMAHAMAN KONSEP HUKUM NEWTON PADA SISWA SMP, Pros. TEP PDs Transform. Pendidik. Abad 21 (2017) 471.

4. P. Klein, A. Müller, and J. Kuhn, Assessment of representational competence in kinematics, Phys. Rev. Phys. Educ. Res. 13 (2017) 1. doi: 10.1103/PhysRevPhysEducRes . 13. 010132 .

5. H. Tms and J. Sirait, "Representations Based Physics Instruction to Enhance Students' Problem Solving," Am. J. Educ. Res. 4 (2016) 1. doi: 10.12691 /education-4-1-1.

6. M. Hill and M. D. Sharma, "Students' representational fluency at university: A cross-sectional measure of how multiple representations are used by physics students Using the representational fluency survey," Eurasia J. Math. Sci. Technol. Educ., 11 (2015) 1633. doi: 10.12973/eurasia.2015.1427a

7. E. Puspitaningtyas, S. Hasanah, S. Kusairi, and E. Purwaningsih, "Physics students' responses when asked to select and solve motion kinematics problems in various representations," AIP Conf. Proc. 2330 (2021), doi: $10.1063 / 5.0043437$

8. B. Ibrahim and N. S. Rebello, Representational task formats and problem solving strategies in kinematics and work, Phys. Rev. Spec. Top.-Phys. Educ. Res. 8 (2012) 1. doi: $10.1103 /$ PhysRevSTPER.8.010126

9. A. Purwanti, Sutopo, and H. Wisodo, Penguasaan Konsep Materi Kinematika pada Siswa SMA Kelas X dengan menggunakan Pembelajaran Multirepresentasi, J. Pendidik. Teor. Penelitian, dan Pengemb. 2 (2017) 575.

10. N. H. Dienyati, I. K. Werdhiana, and U. Wahyono, Analisis Pemahaman Konsep Siswa berdasarkan Multirepresentasi pada Materi Usaha dan Energi Kelas XI SMAN 1 Banawa Tengah, 8 (2020) 74 .

11. H. Liaw, Y. R. Yu, C. C. Chou, and M. H. Chiu, "Relationships between Facial Expressions, Prior Knowledge, and Multiple Representations: a Case of Conceptual Change for Kinematics Instruction,” J. Sci. Educ. Technol. (2020), doi: $10.1007 / \mathrm{s} 10956-020-09863-3$

12. R. J. Beichner, Testing student interpretation of kinematics graphs, Am. J. Phys., 62 (1994) 750 doi: $10.1119 / 1$. 17449

13. P. L. Hale, Kinematics and Graphs: Students' Difficulties and CBLs, Math. Teach. 93 (2000) 414.
14. M. Planinic, Z. Milin-Sipus, H. Katic, A. Susac, and L. Ivanjek, Comparison of student understanding of line graph slope in physics and mathematics, Int. J. Sci. Math. Educ. 10 (2012) 1393. doi: $10.1007 / \mathrm{s} 10763-012-9344-1$

15. M. L. Rosenquist and L. C. McDermott, "A conceptual approach to teaching kinematics," Am. J. Phys., 55 (1987) 407. doi: $10.1119 / 1.15122$.

16. N. Erceg and I. Aviani, Students' Understanding of VelocityTime Graphs and the Sources of Conceptual Difficulties, Croat. J. Educ. Hrvat. časopis za Odgoj i Obraz., 16 (2014) 43. doi: $10.15516 / \mathrm{cje} . \mathrm{v} 16 \mathrm{i1.505}$

17. G. Zavala, S. Tejeda, P. Barniol, and R. J. Beichner, "Modifying the test of understanding graphs in kinematics," Phys. Rev. Phys. Educ. Res. 13 (2017) 1. doi: 10.1103/ PhysRevPhysEducRes.13.020111

18. E. Torigoe and G. Gladding, Same to us, different to them: Numeric computation versus symbolic representation, AIP Conf. Proc. 883 (2007) 153. doi: $10.1063 / 1.2508715$

19. E. Torigoe, How numbers help students solve physics problems, (2011) 1. [Online]. Available: htt://arxiv.org/ $\mathrm{abs} / 1112.3229$

20. E. T. Torigoe, Unpacking Symbolic Equations in Introductory Physics, (2015) 1. Available: htt://arxiv.org/abs/ 1508.00535

21. J. L. Docktor and J. P. Mestre, "Synthesis of discipline-based education research in physics," Phys. Rev. Spec. Top.-Phys. Educ. Res. 10 (2014) 1. doi: 10.1103/PhysRevSTPER. 10.020119 .

22. E. F. Redish and E. Kuo, Language of Physics, Language of Math: Disciplinary Culture and Dynamic Epistemology, Sci. Educ. 24 (2015) 561 doi: 10.1007/ S11191-015-9749-7

23. D.-H. Nguyen, "Students' Difficulties With Multiple Representations in Introductory Mechanics.," Online Submiss 8 (2011) 559 .

24. E. T. Torigoe and G. E. Gladding, Connecting symbolic difficulties with failure in physics, Am. J. Phys. 79 (2011) 133. doi: $10.1119 / 1.3487941$

25. C. S. Hung and H. K. Wu, Tenth graders' problem-solving performance, self-efficacy, and perceptions of physics problems with different representational formats, Phys. Rev. Phys. Educ. Res. 14 (2018) 20114 doi: 10.1103/ PhysRevPhysEducRes.14.020114

26. P. Nieminen, A. Savinainen, and J. Viiri, Erratum to Force concept inventory-based multiple-choice test for investigating students' representational consistency Phys. Rev. Spec. Top.- Phys. Educ. Res. 6 (2010) 5. doi: $10.1103 /$ PhysRevSTPER . 6. 029903 